\title{
RIGA INTERNATIONALAIRPORT DEVELOPMENT IN BALTIC SEA REGION AVIATION INDUSTRY CONTEXT
}

\author{
Sergejs Paramonovs ${ }^{1}$, Ksenija IJeVleva $^{2}$ \\ University of Latvia
}

\begin{abstract}
In the paper the authors examined key Latvian economy indicators, specifically focusing on trends in development of aviation industry development. In particular, also attention was paid to passengers and cargo volume transportation dynamics, as well as to $R I G A$ International Airport Development Plan through the year 2036. The authors compared operations of RIGA International Airport with available data from other leading Baltic Sea Region airports, specifically within 300 kilometres zone. Another requirement was, a competing airport had to be in the TOP 100 airports globally to be considered.
\end{abstract}

KEY WORDS: RIGA International Airport, Baltic sea region, development plan.

JEL CODES: M160, R110, R380

\section{Introduction}

The authors of paper made his work concentrating on factors reflecting in RIGA International Airport efficiency and development. Having a comprehensive plan of RIGA International Airport development in mind, as well as goals set and published in the Year Book 2013 and official website of the airdrome, the authors concentrated their initial efforts on finding a comparable model of airport efficiency tracking to be applied to operations locally. Unfortunately, there was no such the model found. This became a difficult task, what made the authors to rather searching for a relatively applicable concept.

Problem. What is a single or several the most important factors reflecting on the efficiency of the business? To the problem is adding a fact that the majority of airports are still stately owned enterprises and private initiative takes slow to overcome interests of the former ones. In these terms, any work helping to bring efficacy factors analysis onto the table, will shorten the time to bringing private initiative resulting in more effective solutions.

Purpose of the paper is to investigate development of RIGA International Airport within Baltic Sea region airports context.

The object is RIGA International Airport.

1 Sergejs Paramonovs - master degree, University of Latvia, Faculty of Economics and Management. Business Development field

E-mail: sergeypar@yahoo.com

Tel.: +371263706 19

2 Ksenija Ijevleva - doctor degree, University of Latvia, Faculty of Economics and Management. Marketing field.

E-mail: kijevleva@inbox.lv

Tel.: +37126814932 
Tasks. For the purpose accomplishment were implemented the following tasks:

1. Examined academic literature, research results and official reviews of:

- field of aviation and airport operations significance for development of national economy;

- notion of capacity for development in a context of the field of aviation;

- factors affecting aviation enterprises operations;

- development of methods of assessment;

- RIGA International Airport and other Baltic sea region aerodromes' operations.

2. A cluster of factors influencing development of Riga International Airport supplemented and adjusted to its operations.

3. Key Latvian economy indicators were explored, specifically focusing on trends in aviation industry development. In particular, attention was paid to passengers and cargo transportation dynamics, as well as to RIGA International Airport Development Plan through the year 2036.

4. Operations of Riga International Airport were compared with available data from other leading Baltic Sea Region airports, specifically within 300 kilometres zone.

Methods: monographic method and comparison analysis.

\section{Latvian economy main indicators influencing aviation industry}

There is a cluster of social, fiscal and political factors' interplay influence development of national economy at any place in the world. Aviation industry is not an exception. The more national economy is developed and progressing, the more cargo can be transported and residents are able to take flights both for business and leisure purposes (Oxford Economics 2011: 25). Flights taken by passengers, in turn, create stimuli for further intensification of the economy. For example, traveling from place to place, from one country to another, people get new ideas, contacts and contracts, what keeps their motivation self-charging. As a result, airports are prospering and growing, what results in economy new highs, new jobs and improved social stability. According to Biography of IATA CEO Tony Tyler (IATA official website 2014) aviation delivers extensive social and economic benefits, supporting about 57 million jobs and generating 2.2 trillion dollars in total revenues. Margin and profit in the industry is minimal, around two percent against total expenses, but secondary gains were not calculated yet.

Special word should be said about cargo transportation by air carriers. In opinion of IATA Director General Tony Tyler (ACI Airport Economics and Finance Conference in London 13.03.2014), aviation, especially cargo air-freight companies, is feeling the impact of global economic downturn the first. In developed countries, it typically becomes an indicator of declining consumer spending. Center for aviation CAPA provides data (official website) that in 2011, "amid reduced manufacturing confidence and business switching to slower modes of transportation, the air-freight market has shrunk by almost five percent," what was five times higher than one percent downfall in the total world trade. Aviation is the most expensive mean of transportation, but its services are crucial for industry of electronics, for instance. Whenever purchase ability and confidence of consumers are high, this is a heyday for airports and all the industry involved companies.

There are many assumptions made by experts on why RIGA airport is presently showing down-warding or stagnant performance numbers. In the following chart created by the authors on the ground of data available at a portal of Latvia Central Statistical Bureau, there are arrivals (blue bar) with departures (green bar), and cargoes loaded (red line) with cargoes unloaded (blue line) depicted at Figure 1. Accordingly to official statistics of Central Statistical Bureau of Latvia in the year 2011, the airport has served 5.1 million passengers against 4.7 in the following year and 4.8 in 2013. Much stronger performance at cargo loaded and unloaded is possibly showing a proximal zone for development for the RIGA airport in the following years. 


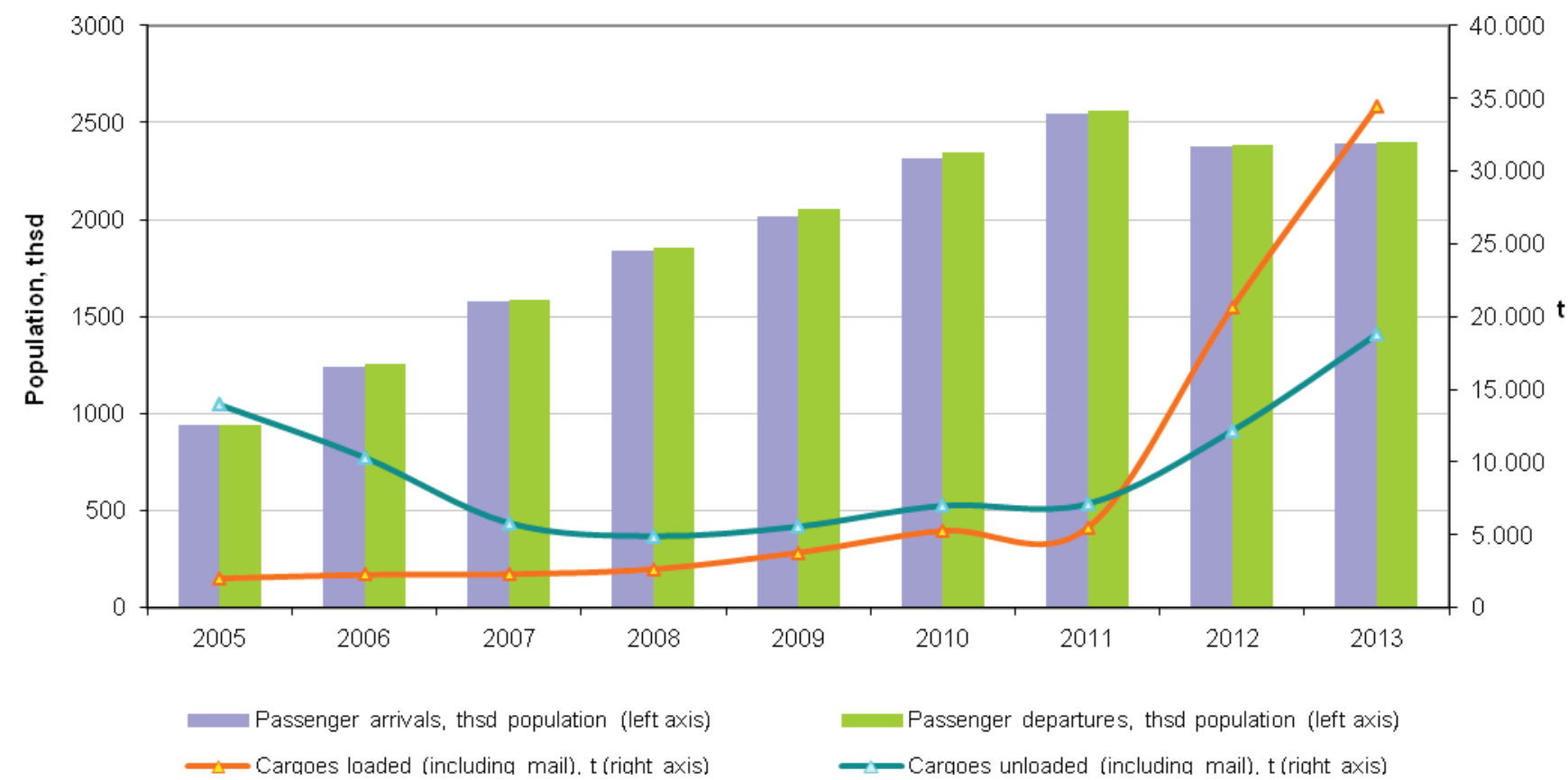

Fig. 1. Traffic at the RIGA International Airport

Source: designed by the authors on the basis of the Central Statistical Bureau statistics

Possible reasons described as dominating airport time-schedules national airline AirBaltic policy changes, pricing and quality of aircrafts and services, geography of connecting flights, as well as limited entertainment. Other possible reasons might be that slow positive changes in economy, along with more flexible pricing strategies by full-service airlines in developed countries make its citizens to choose other destinations both final and for transit. Finally, workers' migration out of the country, possibly, leaves less solvent residents locally, what is not compensated by transit passengers yet.

In the following chart created by the authors on the ground of data available at a portal of Central Statistical Bureau, population of the Republic of Latvia will keep steadily decreasing (Figure 2). Statistics shows that population at the beginning of 2014 year was 2001468 residents. Accordingly to a forecast of Center of Demography at University of Latvia, it will reach 1942074 residents by 2040.

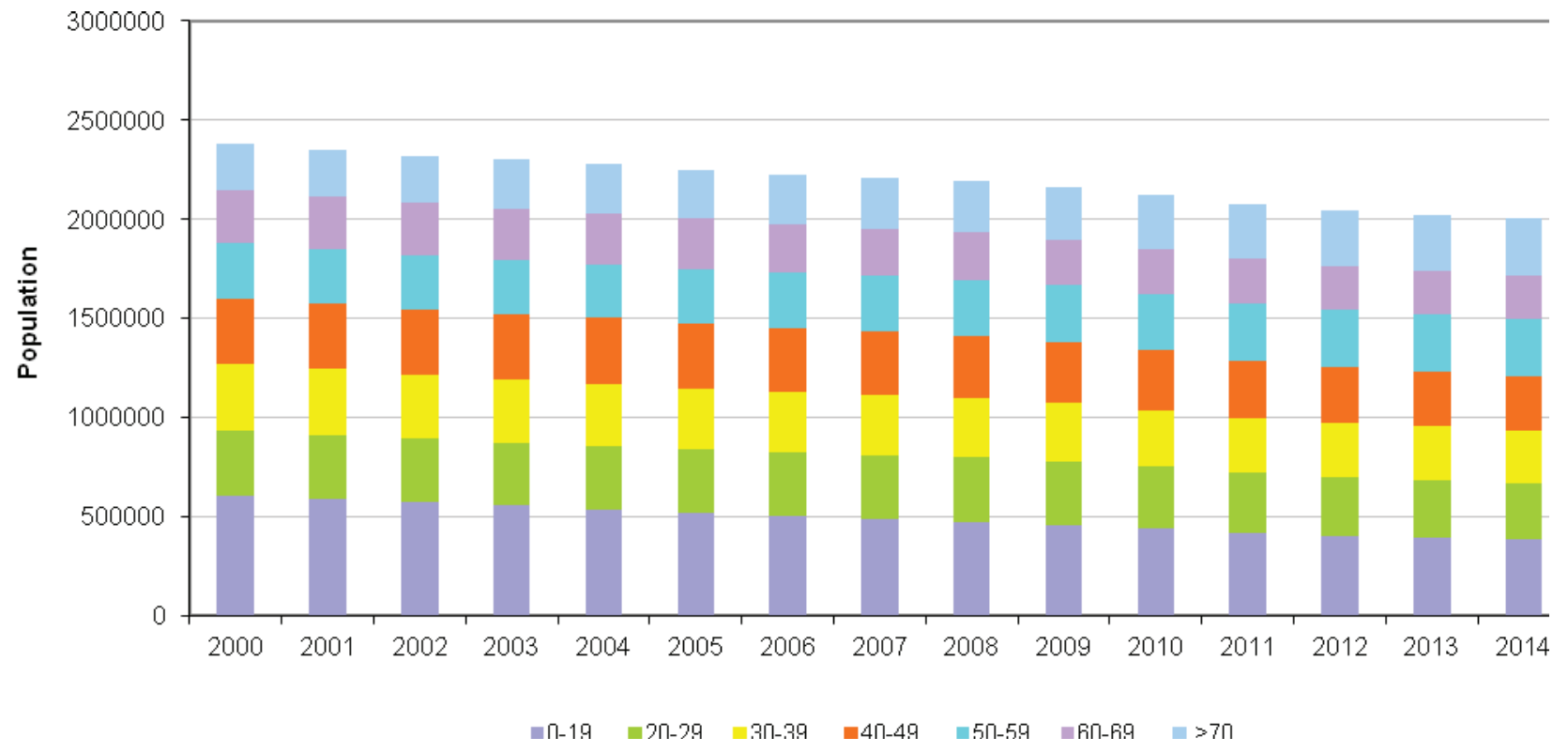

Fig. 2. Latvian resident population by major age groups at the beginning of the year

Source: designed by the authors on the basis of the Central Statistical Bureau statistics 
Presently, of 4.8 million passengers served by the RIGA airport per year 2013, one half is local residents. It comes to 2.4 million passengers' transactions per annum. Roughly, it corresponds to similar numbers at leading airports in the Baltic Sea region. That means, the RIGA airport is almost reached its maximum transactions capacity with local passengers, and its expected growth can be mostly due to passengers coming from neighboring and other countries for transit, leisure and business. However, there is one problem. Competing airports in Tallinn, Vilnius and Kaunas do much to attract passengers from Riga, and recently those often succeed. Cumulatively, in the previous year, they served as many passengers as RIGA airport did. Unlike the later one, those strongly added to their business for the given period.

It is widely accepted, income of country residents is one of the strongest predictors of them to become passengers. In the following chart created by the authors on the ground of data available at a portal of Central Statistical Bureau, monthly average income of residents of the Republic of Latvia is almost staying the same for five years (Figure 3). Similar situation is observed in the rest of the countries within 300 kilometers zone around the RIGA airport.

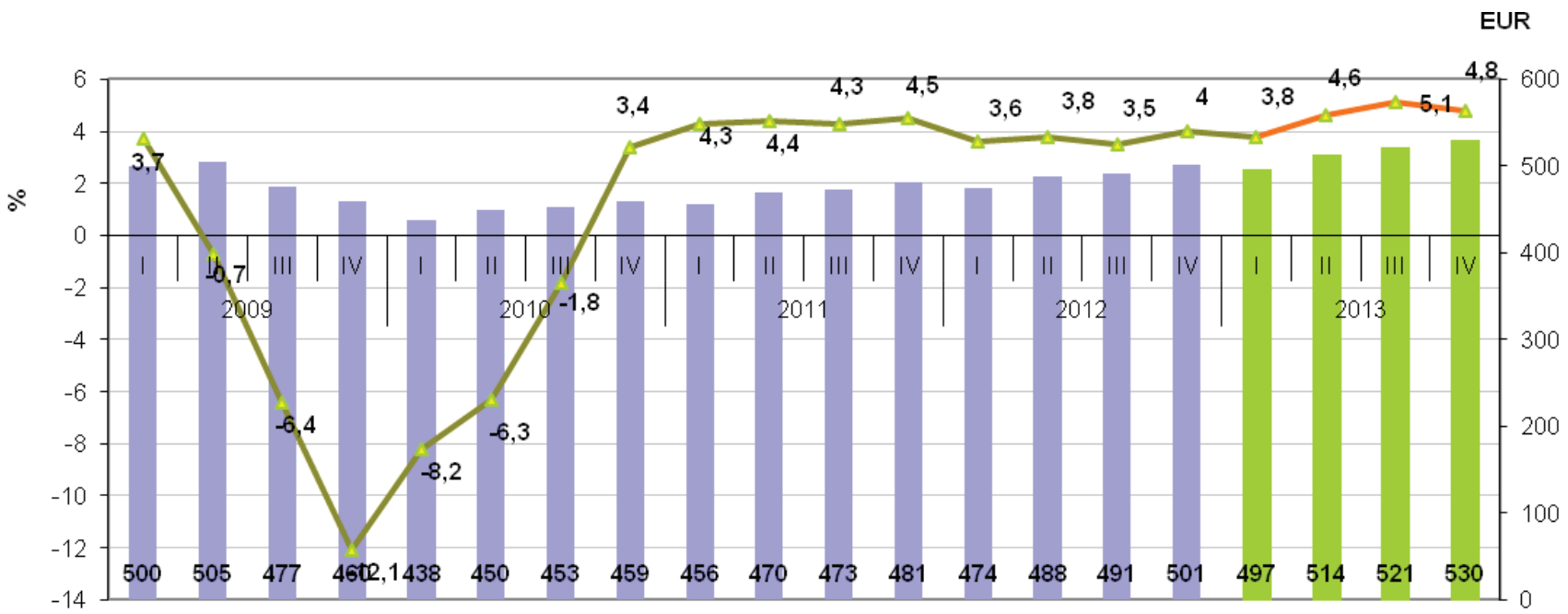

Average net monthly wages and salaries of employees in euro (right axis)

- Average gross monthly wages and salaries of emplovees \% of corresponding period of previous vear (left axis)

Fig. 3. Average net monthly wages in Latvia

Source: designed by the authors on the basis of the Central Statistical Bureau statistics

Besides decreasing number and moderate income of residents mentioned above, performance and statistics of RIGA airport operations are strongly influenced by Gross Domestic Product (GDP), inflation and unemployment rate. A portal of Ministry of Economics of Latvia reports improving situation in national economy (official website, 2013). But, a steady trend on improvement in volume of GDP, export and unemployment are still not sufficient to create a local mass of residents to extensively travel and show increase on this number in the airport statistics. Despite the fact of Latvia residents leaving for good and work, unemployment rate of 12 percent is still too high. In its part, Bank of Latvia reports low inflation level, between one and two percent in 2013 (official website). This will help the airport administration to better plan their budget and finances.

In the following chart created by the authors, and on the ground of data available at a portal of Latvia Central Statistical Bureau for the previous six years, GDP, inflation and unemployment rates are shown as follows. GDP in Latvia is EUR 31.5 billion, what calculates into approximately EUR 16 thousand per capita, the number is similar to the neighboring countries, but, on average, two to three times less than in the rest of the Baltic Sea region countries. The red line reflects inflation with its lows and highs for the previous six 
years. The highest inflation observed was in the first quarter of 2014, and the lowest at five percent deflation level in the third quarters of 2009 and 2013. The present level at 1.2 percent is estimated by the Bank of Latvia as low. But, blue line of unemployment rate shown on the chart is showing positive for aviation industry dynamic, while decreasing up to 12 percent this year (Figure 4).

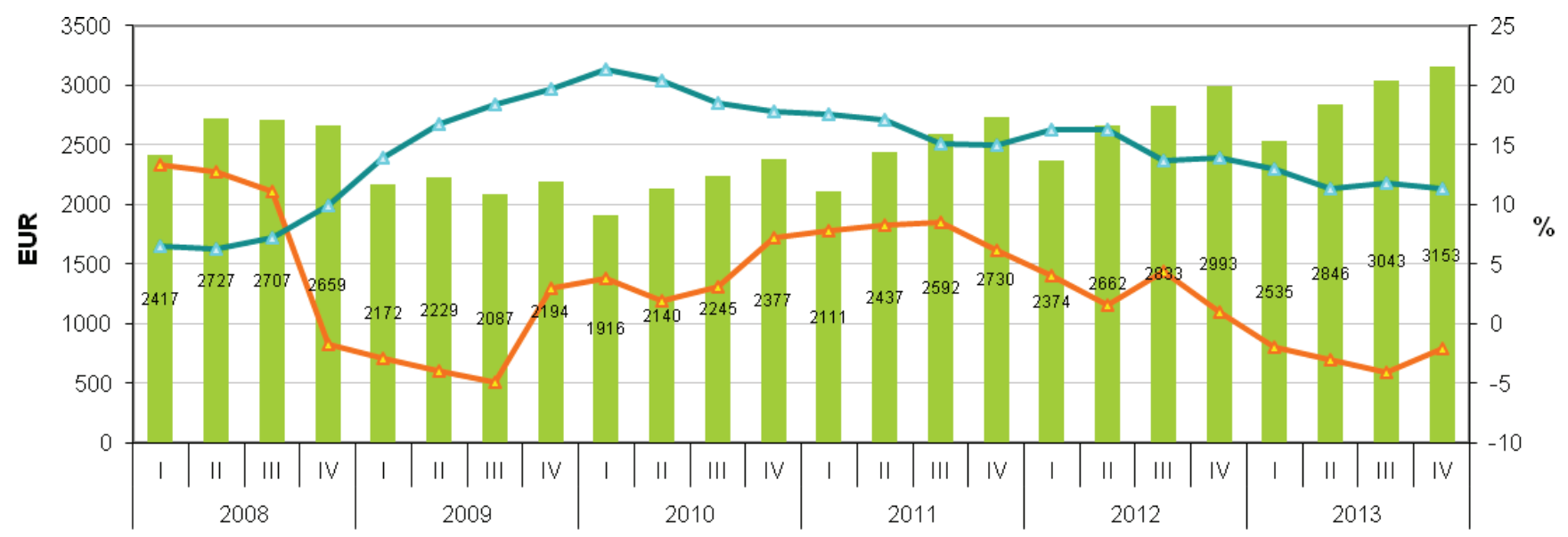

\footnotetext{
GDP per capita from, at current prices, seasonally unadjusted, in euro (left axis)

- Consumer price changes $\%$ over the corresponding period of previous year in transport field (right axis)

- Share of unemployed to the active population, \% (right axis)
}

Fig. 4. Key indicators of Latvian economic situation in 2008-2013 years

Source: designed by the authors on the basis of the Central Statistical Bureau statistics

Taking data and information used above into consideration, one may conclude that residents of Latvia have comparably lower solvency and are scarce in number. The dynamic is not showing strong improvements for the previous five years and little points at possible positive changes in the near future. While planning expansion of its services, it is recommended, RIGA International Airport to primarily concentrate on cargo freights, transit passengers, as well as on non-resident travellers coming for business, but mostly for leisure. The continuous tendency for population of Latvia to decrease in numbers is stopped, what is a positive sign. It will let the airport administration to better research passengers' preferences and prepare optimal sets of packages to satisfy their needs.

\section{RIGA International Airport development plan analysis}

The existing Plan of RIGA International Airport Development until the year 2036 was elaborated by "Infra Projekti" Limited corporation (Riga), being ordered by the Ministry of Transportation of Latvia in the year 2011. The enterprise coordinated mutual forces of numerous state and privately owned bodies. The resulting document includes a clear eight stages step-by-step lead to follow in an attempt to make the airdrome either Europe regional or Eurasia hub. It is said, four stages were completed by the year 2012 already (Summary of development plan of the RIGA International Airport 2012-2036). The following stages are - stage five or Northern Terminal construction phase; during stage six there will be existing terminal remodeled to implement automatic passengers serving technologies, new multi-level parking and hotels erected, as well as waiting and areas for rest expansion; for stage seven it is planned to remodel commercial properties in the main terminal; final stage will be culminated by building South Terminal.

Two proposed scenarios of development are forecasting number of served passengers up to 9.9 and 13.8 million correspondingly. The authors of the plan admit that their vision is very conservative due to their previous failures to predict possible downturns in economics (Summary of development plan of the RIGA International Airport 2012-2036: 40). They even go further and state that both scenarios are not possible to 
implement for the moment, because the process has stuck on the stage five, or building a new terminal. We are not even talking about necessary ecological projects of constructing a platform for deicing of aircrafts. Presently, the deicing liquid is simply dispensed onto the ground -800 kilograms per airplane. And this is just one of the important ecological projects not mentioned in the plan.

On the ground of available in the document data, the authors of the paper have calculated that in the first case scenario the airport will keep transit traffic to the same as presently 36.8 percent, compared to 60 percent in the second. Though, it is not clear, on what ground is made an assumption of local passengers' traffic to double by the year 2020. As it is known, present data on passengers' traffic growth of the RIGA airport is negative, as compared to indicators of all the major competitors. For example, Copenhagen Airport (CPH) came with all times high passengers traffic increase for the first quarter of the year 2014 (official website). To add, there is nothing said in the plan of how to marketing potential passengers' body and attract them.

There are six factors delaying implementation of both European Hub and Eurasia Hub scenarios of the plan reported. Airport technical development is stuck on the fifth stage of realization; flight management and structure is not effective at rush hours; AirBaltic traffic structure is not flexible; Ryanair is planning to reduce its presence at RIGA airport after the year 2015; the airport is raising its service fees due to increased operational expenses; and difficulties raising from national air carrier's operations. Special attention should be paid to an assertion in the document that the airport is barely managing through its daily rush hours. The facts of difficulties in providing basic needs of passengers in ventilation, air-conditioning, toilet and getting to and from the airplane are reported. Additionally, limited capacity of the runaway ( 32 operations per hour) makes reaching the goals complicated (development plan: 42-43).

The main objective of the plan is to provide guidance for further development of the establishment, while meeting the demand for sustainable and financially justified airport services. In understanding of the authors, the development of the airdrome is seen in the document as creating and maintaining well formulated and calculated services targeting oncoming demand.

Another strategic goal stated is to create favorable and non-discriminatory conditions for all employees and businesses, as well as adequate airport infrastructure. The prospective is to reach the goals in cooperation with existing and new airlines ready to expand their routes and presence at RIGA airport. It is necessary to create favorable preconditions for particular airlines, like Finnair and Scandinavian Airline System (SAS) to choose Riga as their hub location. This is due to the fact both airlines clearly highlighted their trend of development toward Eurasia traffic routing (development plan: 40-41). Finding and attracting a new strategic partner-airline is stated as one of the most important tasks in the plan, as this will create better competing business environment and become the only way to implement Eurasia Hub prospective.

Summarizing, the plan of development for RIGA airport is well thought and elaborated accordingly to international aviation industry standards (ICAO official website), European and Latvian laws and regulations. The plan is comprehensive. It covers almost all aspects of securing sustainable and growing long-term operations. Important, environmental issues are given special and growing attention in both the document and actual implementation. Problems with financing the project are described and solutions offered. In opinion of the authors of the paper, the weakness of the plan is absence of ongoing or longitudinal benchmarking to industry or regionally best airports. Another significant problem is that national air-carrier AirBaltic, not really full-service airline, totally dominates existing operations with 63 percent flights coverage, but planning to increase its operations to exceed existing capacity of the airport in several years.

Unfortunately, there is no break through solutions and venues in the plan presented of how to make the RIGA airport experience unforgettable for passengers. For example, the airport in Copenhagen (CPH) offers variety of gourmet restaurants, but Amsterdam Airport Schiphol offers the best shopping, connection and facilities for conferences (Amsterdam Airport Schiphol official website). The later one is true Airport City, where everything is at hand's reach. The experts employed by the authors, being the board members, expressed their vision for the RIGA airport to become exactly the Airport City, rather than airport in the city. 


\section{RIGA International Airport development in Baltic Sea region aviation industry context}

Nowadays, Baltic Sea region is one of the most rapidly developing in Europe, whilst demonstrating strong economical and political potential. Its strategic significance became even stronger after the most of the countries in the region have joined European Union (EU) and North Atlantic Treaty Organization (NATO). Elaboration of EU strategy for Baltic Sea region is one of those initiatives, where Latvia is actively participating from the very moment of the idea's emergence. During EU Denmark's presidency in the year 2012, there were elaborated three strategic goals for the Baltic Sea region development - saving and protecting the Sea; unification of the region; and increasing the welfare of its population (EU Baltic Sea region strategy 2012). In its part, European Security and Defense Policy (ESDP) states the necessity to support and develop the regions and cities to become more dynamic, competitive, prosperous and attractive (available at http:// www.vraa.gov.lv). Finally, to minimize functional barriers for transportation flows, innovations introduction and its implementation, the second priority of the Baltic Sea Region Transnational Cooperation Program calls for further facilitation of internal and external accessibility of the regions; and further introduction and development of the transnational logistics, as well as information and communication technology projects (available at http://www.varam.gov.lv).

In this context, aviation is supposed to be given special attention, as this is the fastest transportation available up-to-date. Aviation enhances economic performance and improves connectivity to the wider economy through enforcement of its overall level of productivity and cooperation. This results in domestic firms getting increased access to foreign markets and increased foreign competition in the home market, as well as to free movement of investment capital and workers between countries. In Sweden, for example, overall, registered airlines altogether contribute 1.2 billion Euros into the economy and support 13,000 jobs (Oxford economics 2011).

The authors have decided to make airports a primary concentration of this paper part, as those are the most significant objects of infrastructure for expansion of the aviation industry. Those are both strategic places but, recently, more and more commercial venues. Airports are very complex structures and enterprises, and their functioning should not be estimated solely by analyzing performance of its integrated parts - sites, facilities, equipment, administration, service teams, suppliers, commercial venues and security - but as a whole amalgamated system. It appears that until now there is no uniform comprehensive Key Performance Indicator (KPI) system elaborated, accepted and available for European or Baltic Sea region airports. This is why the authors consider this work to be of higher importance.

\subsection{Aviation development prospective for European and Baltic Sea airports}

Baltic Sea aviation exists within the mainstream development of European aeronautical industry and its supporting regulations. With about 150 scheduled airlines, a network of over 450 airports, 60 air navigation service providers and 10 million flights per year and forecasted future growth the European airspace is one of the busiest and most complex in the world (Eurocontrol Annual Report 2012). In 2011 a total of $1,569,907,313$ passengers travelled from and between European airports, representing a share of around $28.84 \%$ of total passengers travelled in the world (World Airport Traffic Report 2011). Air transport makes a key contribution to the European economy. The aviation sector employs more than 4.5 million people. Airlines and airports alone contribute $1.5 \%$ to the European GDP (Thelle, Pedersen, Harhoff 2012).

Despite the impact of the financial crisis and other external pressures, aviation industry experts still expect enormous growth in the long-run, as forecasts of various institutions predict increasing traffic volumes for the next decades (official website of Airbus 2014). Aerodromes represent one of the major bottlenecks for future expansion of the global air transport system. However, in contrast to airlines, which can increase their offered capacity relatively fast through acquisitions of new planes, airports need to enlarge their capacities through huge infrastructure investments, while at the same time the fees they can charge their customers are capped by national laws (De Neufville, Odoni 2003: 883). 
This leads to a growing importance of non-aeronautical and commercial revenues, which today account for around $50 \%$ of airports total earnings, with variations across global regions. Other challenges the airport industry faces today are new patterns of demand growth, pressure for reduced charges, fewer subsidies, environmental issues, increased regulation and the change from governmental owned infrastructure providers towards privately operating companies (De Neufville, Odoni 2003: 883).

The basic process behind these terms can be described as airports moving from public sector ownership and national requirements towards an industry ruled by the private sector and global corporations. However, turning former public administration structures into competitive companies requires business practices. One aspect of this change is the measurement of the own performance. Due to the described increased commercial focus, airports try to get deeper insights into their operations by measuring their performance with the right indicators. Besides using the metrics as business steering instruments, measuring the right metrics enables airports to use this knowledge for internal and external benchmarks as well (World Airport Traffic Report 2012). To realize operational safety, gain financial efficiency and monitor environmental impacts, airport managers rely more than ever on trustworthy and effective performance measurement (Fry, Humhpreys 2001). In the next part of paper the authors determine the tendencies of Latvian aviation industry.

\subsection{Latvian aviation industry development from the prospective} of RIGA International Airport

Latvia Aviation Department at Ministry of Transportation implements a state policy and governance of civil aviation industry. The Republic of Latvia Ministry of Transportation has elaborated and accepted a plan of aviation industry and RIGA airport development until the year 2020. Accordingly to the document, the primary goal is set as to develop an economically efficient air transportation system that provides residents, visitors and transfer passengers with safe, qualitative, reliable and affordable services (Official website of LR Ministry of Transport).

Reasonable pricing, further stabilization and development of the national air carrier AirBaltic, launching a comprehensive program of regional aviation emergence and development, searching and entering into agreements with other governments and industry related organizations, coordination of plans of development with airports across Europe, joining the international treaties and agreements, standing for the interests of Latvia in European aviation regulating bodies, strengthening the legislative and regulations enforcement base, further enhancement in domains of consumer rights and environment protection are targets mentioned in the document. Of special attention is made to stress the need for continuation of integration of Latvian aviation industry into European Union program called Single Sky, while introducing and implementing new safety and security technologies.

The existing plan of RIGA airport development includes construction of the second runway, new control tower, another terminal adjoined to the existing one, business park around the site, hotel, and either of train or tram line to the center of the city, as well as expansion of registration and commercial space. In case of fulfillment, the plan will result in significantly increased capacity (up to 15 million passengers per annum) and actual increase in turnover of passengers choosing Riga as a final or destination for a transfer. In other words, better, technically secure and safer operations; more flights, destinations and passengers are expected.

Accordingly to the document, the target is set to serve about 7 million passengers annually, starting from the year 2020. In terms of macroeconomics, while targeting a share increase of aviation industry in the Latvian economy, there is a strong orientation set toward export and facilitation of development of cooperation with associated and secondary industries of tourism and hospitality, food and beverage, art-craftwork and retail, transportation and entertainment, as well as beauty and healthcare. Ultimately, Latvia and Riga are seen as safe, competitive and steadily developing region and transportation hub of western European level, efficiently connecting East and West by a network of flights.

Implementation of the plan has already been started. On November 1 $1^{\text {st }}, 2012$ RIGA International Airport had entered into agreement with the winner of a restricted tender procedure - the unlimited partnership FCC, Hochtief and ACB - for construction works. The project is co-financed by the European Union Cohesion 
Fund, Latvian government and RIGA airport. Accordingly to RIGA International Airport Yearbook 2012 construction works had started in May 2013 and will be completed in 16 months. The following works will be carried out in the period until 31 August 2014: renovation of the runway pavement; improvement of the runway strip and the runway end safety area; construction of two new taxiways; modernization of the runway lighting system; reconstruction of the storm water and aerodrome drainage system; reconstruction of Aprons 2 and 3; construction of two new anti-icing pads; construction of a vehicle washing hangar; construction of a waste collection site; introduction of CAT II lighting system on the taxiways.

\section{Baltic Sea Region TOP10 Airports - Learning from the Best}

Analyzing statistics from available sources, the authors decided to build a chart of 10 top airports of the Baltic Sea region. While working on the review-study, it was decided by the authors to omit several airports in the region from the list, as those were less representative of what could be further used for development of Latvian aviation industry. For instance, Russia's airports of St. Petersburg and Kaliningrad, as well as leading German airports were put off the chart as, by opinion of the authors, less appealing to the economy of Latvia by its size, efficiency and multidimensionality. Technically, in the statistics given below, there is another less appealing and comparable to Latvia's economy example of airport in Warsaw; it is more centrally located in Europe and due to historical reasons it serves 38.5 million Polish population while keeping them connected to relatives all over the world. Therefore, it was decided to concentrate on Baltic and Nordic regions as closely related ones. For the reason of keeping data comprehensible without applying statistical methods of analysis, the authors created a chart of TOP10 airports (see Table 1). Key indicator in ranging the airports became total passenger turnover per year 2012.

Table 1. Baltic Sea Region Top 10 Airports Ranking and Key Indicators in the Year 2012

\begin{tabular}{|l|l|l|l|l|l|}
\hline \multicolumn{1}{|c|}{ Airport } & Rating & \multicolumn{1}{|c|}{ Population } & \multicolumn{1}{c|}{ Passengers } & \multicolumn{1}{c|}{$\begin{array}{c}\text { Aircraft } \\
\text { movements }\end{array}$} & $\begin{array}{c}\text { Mail } \\
\text { (Million Tons) }\end{array}$ \\
\hline Copenhagen, Denmark & 16 & $560 \mathrm{~K}$ & $23335 \mathrm{~K}$ & $243 \mathrm{~K}$ & 157 \\
\hline Oslo, Norway & 19 & $600 \mathrm{~K}$ & $22080 \mathrm{~K}$ & $237 \mathrm{~K}$ & 104 \\
\hline Stockholm, Sweden & 22 & $800 \mathrm{~K}$ & $19678 \mathrm{~K}$ & $210 \mathrm{~K}$ & 75 \\
\hline Helsinki, Finland & 29 & $600 \mathrm{~K}$ & $14858 \mathrm{~K}$ & $172 \mathrm{~K}$ & 192 \\
\hline Warsaw, Poland & 42 & $2000 \mathrm{~K}$ & $9588 \mathrm{~K}$ & $118 \mathrm{~K}$ & 43 \\
\hline Bergen, Norway & 66 & $265 \mathrm{~K}$ & $5814 \mathrm{~K}$ & $104 \mathrm{~K}$ & 7 \\
\hline Gothenburg, Sweden & 75 & $525 \mathrm{~K}$ & $4854 \mathrm{~K}$ & $61 \mathrm{~K}$ & 37 \\
\hline Riga, Latvia & 76 & $700 \mathrm{~K}$ & $4768 \mathrm{~K}$ & $69 \mathrm{~K}$ & 33 \\
\hline Stavanger, Norway & 82 & $200 \mathrm{~K}$ & $4414 \mathrm{~K}$ & $86 \mathrm{~K}$ & 4 \\
\hline Trondheim, Norway & 89 & $170 \mathrm{~K}$ & $4160 \mathrm{~K}$ & $61 \mathrm{~K}$ & 5 \\
\hline K is & & & &
\end{tabular}

( $\mathrm{K}$ is equal to 1000 )

Source: designed by the authors on the basis of the mentioned airports official web-sources

This is not in the chart, but most of international travelers from TOP4 Baltic Sea region airports (Table 2) taking flights to TOP4 destinations - 5 million passengers travel annually to London Heathrow; 2.2 million to Paris (CDG); 2.2 to Amsterdam; 2.1 to Frankfurt. The TOP4 European destinations are real huge transportation hubs, which altogether turned 240 million passengers over in the year 2012. To add, TOP4 London airports are turning over 133 million passengers per year, of which London Heathrow is accountable for $50 \%$ of the figure.

TOP4 non European destinations from TOP4 Baltic Sea region airports are New York, USA - about 1 million passengers; Bangkok - 0.85 million passengers; Antalya - 0.71 million from top 3; un Istanbul - 0.55 million from two airports. 
Table 2. Baltic Sea Region Top 4 Airports and RIGA International Airport Benchmarking by Key Indicators in the Year 2012

\begin{tabular}{|c|c|c|c|c|c|c|c|}
\hline \multirow[t]{2}{*}{ Airport } & \multirow[t]{2}{*}{ Airlines } & \multirow[t]{2}{*}{ Destinations } & \multicolumn{2}{|c|}{$\begin{array}{c}\text { Passengers } 2002 \\
\text { (million) }\end{array}$} & \multicolumn{2}{|c|}{$\begin{array}{c}\text { Passengers } 2012 \\
\text { (million) }\end{array}$} & \multirow[t]{2}{*}{ Punctuality } \\
\hline & & & Local & Inter. & Local & Inter. & \\
\hline Copenhagen, Denmark & 63 & 111 & $1.7 \mathrm{M}$ & 16.6 & 1.9 & 21.4 & $86.2 \%$ \\
\hline Oslo, Norway & 52 & 128 & $6.9 \mathrm{M}$ & 6.5 & 9.8 & 11.7 & $86.7 \%$ \\
\hline Stockholm, Sweden & 66 & 177 & $6 \mathrm{M}$ & 10.4 & 4.8 & 14.8 & $83.4 \%$ \\
\hline Helsinki, Finland & 56 & 80 & $2.8 \mathrm{M}$ & 6.8 & 2.7 & 12.1 & $94.3 \%$ \\
\hline Riga, Latvia & 23 & 83 & $0.1 \mathrm{M}$ & 0.6 & 0.1 & 4.7 & $99.8 \%$ \\
\hline
\end{tabular}

Source: designed by the authors on the basis of the mentioned airports official web-sources

Below are four short articles describing the best experiences of TOP4 Baltic Sea region airports. Each of the airports historically has developed some specialization. In some way, each of the airports is unique. These strengths of each airport are marked as International HUB; Environment; Efficiency and Technology; and Cargo, Precision and Modesty. For instance, Cargo stands for the best and most efficient experiences in handling and transporting cargo, Precision and Modesty is about keeping numbers tight - investments and projects are planned tightly to numbers of expected capacity of growth in the near future.

\section{Conclusion}

Accordingly to LR Ministry of Transportation the target was made for the aviation industry to become one of the leading in the Baltic Sea region. RIGA International Airport already today handles almost as many passengers as Tallinn, Vilnius and Kaunas taken together, demonstrating the dominance as the Baltic aviation hub.

However, for now it is not cost effective for air carriers to land larger aircrafts in Riga, what would become crucial for further expansion of RIGA International Airport network of direct destinations. Latvia doesn't have any 5 star hotel of the world class. There is the whole cluster of passengers, who will not consider this destination on the ground if this reason only. The authors consulted with major investors on the matter, but always received the answer that there is nothing is ready in Latvia to launch such a project. The investors have mentioned two primary reasons for their skepticism - the government policies and corruption.

Dynamic development depends on easy access to services and resources. Good accessibility, effective timely, and moderately priced logistics are among the most important factors businessmen consider before they make a decision to start operations in any location.

RIGA International Airport has just entered competition with really strong competitors - airports of Scandinavian capitals. The TOP4 Baltic Sea region airports are located in countries with prosperous economies, extended business networks and very rich culture. Knowing that the competitors offer better service time, quality and range of destination they fly to, RIGA International Airport administration has to reevaluate strategic positioning or vision while attempting to go beyond of what they offer.

Recognizing disadvantages of Latvian economy, the only possibility for development of Latvian aviation industry is attracting more transit and international passengers. Doing so, Latvia need larger airports, more airlines, and wider network of destinations, increased frequency and efficient connections between the flights across the air carriers. 


\section{References}

Amsterdam Airport Schiphol official website. Available https://plus.google.com/+schiphol/posts Retrieved 21.05.2014. Attractiveness of European Regions and Cities for Residents and Visitors. European Spatial Planning Observation Network projects and researches. Available http://www.vraa.gov.lv/lv/starptautiska_sadarbiba/espon_contact/ Retrieved 02.11.2013.

Baltic Sea Region Programme 2007-2013. Available at http://www.varam.gov.lv/lat/fondi/ets/bjr_tsp/ Retrieved 02.11.2013.

Bank of Latvia official website. Available http://www.bank.lv/presei/par-inflacijas-dinamiku Retrieved 10.05.2014.

Biography of IATA CEO Tony Tyler. (2014). Available on IATA official website: https://www.iata.org/pressroom/pages/ ceo-biography.aspx Retrieved 01.05.2014.

Center for aviation CAPA official website. Available http://centreforaviation.com/analysis/airlines-and-airports-feelingimpact-of-global-economic-weakness-with-continued-freight-pressures-ev-63705 [retrieved 01.05.2014].

Centre of Demography, University of Latvia, Statistics. Available http://www.popin.lanet.lv/en/index_eng.html [retrieved 10.05.2014].

Copenhagen airport official website. Available http://www.cph.dk/en/ [retrieved 21.05.2014].

De Neufville, R., Odoni, A. (2003). Airport Systems: Planning Desigh, and Management. $2^{\text {nd }}$ Ed. 883 p.

Economic Benefits From Air Transport in Sweden. (2011). Oxford economics. Available http://www.svensktflyg.se/wpcontent/uploads/2011/10/economic-benefits-from-air-transport-in-sweden-v1.1.pdf [retrieved 02.11.2013].

Economics Benefits from Air Transport in Latvia. (2011). Oxford Economics, Abbey House. OXFORD OX1 1HB, UK, p. 25.

EU Baltic Sea region strategy. Available http://www.mfa.gov.lv/lv/Arpolitika/eu/es-strategija/ [retrieved 02.11.2013].

Eurocontrol Annual Report 2012. Available www.eurocontrol.int/documents/eurocontrol-annual-report-2012 [retrieved 02.11.2013].

Fry, J., Humhpreys, I. (2001). An international survey of performance measurement in airports. Performance Management Research Unit, Open University Business School, Walton Hall, Milton Keynes.

Internation Civil Aviation Organization official website. Available http://www.icao.int/Pages/default.aspx [retrieved 21.05.2014].

Ministry of Economics of the Republic of Latvia official website. Available http://em.gov.lv/em/2nd/?id=33397\&cat=621 [retrieved 10.05.2014].

Official site of LR Ministry of Transport. Available www.sam.gov.lv/satmin/content/?cat=95 [retrieved 10.12.2013].

Official statistics of Central Statistical Bureau of Latvia. Available websitehttp://data.csb.gov.lv/Table. aspx?layout=tableViewLayout $1 \& p x \_t a b l e i d=T R 0300 . p x \& p x \_p a t h=t r a n s p \_$Ikgad\%c4\%93jie $\% 20$ statistikas $\% 20$ dati_Transports\&px_language $=$ en\&px_db=transp\&rxid $=$ cdcb978c-22b0-416a-aacc-aa650d3e2ce0 [retrieved 05.05.2014].

Official website of Airbus. Available www.airbus.com/company/market/orders-deliveries/airbus-press-conference/ [retrieved 02.03.2014].

Remarks of Tony Tyler at the ACI Airport Economics and Finance Conference in London (13.03.2014). Available on IATA official website: http://www.iata.org/pressroom/speeches/Pages/2014-03-13-01.aspx [retrieved 01.05.2014].

RIGA International Airport Yearbook 2012. Available http://www.riga-airport.com/uploads/files/Gadagramata_2012 ENG_Final.pdf [retrieved 11.05.2014].

Summary of development plan of the RIGA International Airport 2012-2036. Available http://www.RIGA-airport.com/ uploads/files/Par\%20lidostu/Lidostas_attistibas_plana_kopsavilkums.pdf [retrieved 30.11.2013].

Thelle, M. H., Pedersen, T. T., Harhoff, F. (2012, June). Airport Competition in Europe. Copenhagen economics.

World Airport Traffic Report 2012. Airports Council International. Available http://www.aci.aero/News/Releases/ Most-Recent/2013/09/03/ACI-Releases-its-2012-World-Airport-Traffic-Report-Airport-Passenger-Traffic-Maintains-Momentum--Cargo-Growth-Remains-Almost-flat-for-Second-Year--as-Advanced-Economies-Face-Austerity- [retrieved 10.12.2013].

World Airport Traffic Report 2011. Airports Council International. Available www.aci.aero/News/Releases/Most-Recent/2012/08/27/ACI-Releases-its-2011-World-Airport-Traffic-Report-Airport-Passenger-Traffic-Remains-Strongas-Cargo-Traffic-Weakens [retrieved 12.04.2014] 


\section{RYGOS TARPTAUTINIO ORO UOSTO PLËTRA BALTIJOS JÜROS REGIONOAVIACIJOS VERSLE}

Sergejs Paramonovs, Ksenija Ijevleva

Latvijos universitetas

Santrauka

Straipsnyje autoriai analizavo Latvijos ekonominius rodiklius, ypač kreipdami dėmesị ị aviacijos verslo plètrą. Be to, analizuojama kelevių ir krovinių gabenimo dinamika, ypač Rygos tarptautiniame oro uoste. Analizuojamas šio oro uosto plètros planas iki 2036 metų. Autoriai lygino Rygos tarptautinio oro uosto duomenis su kitų Baltijos jūros regiono uostų duomenimis, analizè atlikta 300 kilomentrų spindulio zonoje. Kitas lyginimui svarbus kriterijus - oro uostas turi būti pasauliniame šimtuke, t. y. tarp geriausių oro uostų. Artimiausi stiprūs konkurentai - Skandinavijos oro uostai, teikiantys kokybiškas paslaugas. Siekiant plètoti aviacijos verslo šaką, rekomenduojama stengtis kuo daugiau pritraukti tranzitinių krovinių ir keleivių.

PAGRINDINIAI ŽODŽIAI: Rygos tarptautinis oro uostas, Baltijos jūros regionas, plètros planas.

JEL KLASIFIKACIJA: M160, R110, R380 